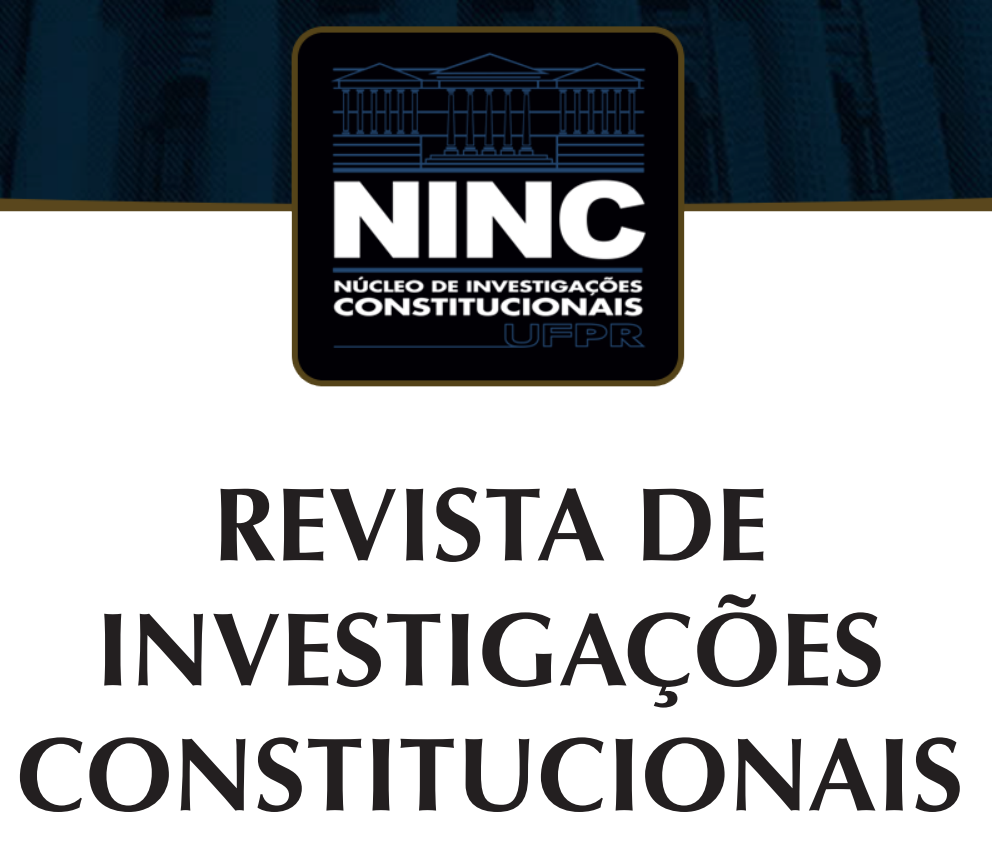

JOURNAL OF CONSTITUTIONAL RESEARCH

vol. 5 | n. 3 | setembro/dezembro 2018 | ISSN 2359-5639 | Periodicidade quadrimestral Curitiba | Núcleo de Investigações Constitucionais da UFPR | www.ninc.com.br 


\section{Beyond futebol and language: what have we missed from not paying Brazilian constitutionalism its due attention? Reflections from Chile}

\section{Para além do futebol e do idioma: o que perdemos por não ter dado ao constitucionalismo brasileiro a devida atenção? Reflexões a partir do Chile}

PABLO CONTRERAS*

Universidad Alberto Hurtado (Chile) pacontrv@uahurtado.cl

DOMINGO LOVERA**

Universidad Diego Portales (Chile) domingo.lovera@udp.cl

Recebido/Received: 13.08 .2018 / August $13^{\text {th }}, 2018$ Aprovado/Approved: 25.08.2018 / August 25 th, 2018

Abstract

This essay proposes a critical and comparative reflection focusing on the lack of 'constitutional dialogue' Chile has developed with Brazil - and vice versa. After proposing a couple of contentions to explain this lack of attention (cultural and constitutional colonialism, on the one hand coupled with Brazil geopolitical power, on the other), it moves on to lament what this lack of attention has deprived Chile from. As it discusses the means to overcome the lack of legitimacy that affects Chile's constitutiona text, it calls attention to some of the reasons that may
Resumo

Este ensaio propõe uma reflexão crítica e comparativa com foco na falta de "diálogo constitucional" que o Chile desenvolveu com o Brasil - e vice-versa. Depois de propor algumas disputas para explicar essa falta de atenção (colonialismo cultural e constitucional, por um lado, aliado ao poder geopolítico do Brasil, por outro), passa a lamentar o quanto essa falta de atenção prejudicou o Chile. Ao discutir os meios para superar a falta de legitimidade que afeta o texto constitucional do Chile, chama a atenção para algumas das razões que podem explicar, e na realidade

Como citar esse artigo/How to cite this article: CONTRERAS, Pablo; LOVERA, Domingo. Beyond futebol and language: what have we missed from not paying Brazilian constitutionalism its due attention? Reflections from Chile. Revista de Investigações Constitucionais, Curitiba, vol. 5, n. 3. p. 117-135, set./dez. 2018. DOI: 10.5380/rinc.v5i3.60976.

"Assistant professor at Universidad Alberto Hurtado (Santiago, Chile). S.J.D. at Northwestern University (Evanstone, United States of America). LL.M. at Northwestern University. M.A. at Universidad Alberto Hurtado. E-mail: pacontrv@uahurtado.cl.

"* Assistant professor at Universidad Diego Portales (Santiago, Chile). Ph.D. at Osgoode Hall Law School (North York, Canada). LL.M. at Columbia University (New York, United States of America). E-mail: domingo.lovera@udp.cl. 
explain, and actually justify, the celebratory tone the Brazilian Constitution's $30^{\text {th }}$ anniversary has acquired.

Keywords: Brazil; Chile; constitutional change; Constitutional Law; comparative constitutionalism. justificar, o tom celebratório que o aniversário de 30 anos da Constituição brasileira acabou por adquirir.

Palavras-chave: Brasil; Chile; mudança constitucional; Direito Constitucional; constitucionalismo comparado.

\section{CONTENTS}

1. Introduction; 2. Brazil: A foreign neighbor? 3. Brazil as a (proud constitutional) continent; 4. A democratic transition as a factor for exceptionalism; 5. Some conclusions: Excuse us, we are lost; $\mathbf{6}$. References.

\section{INTRODUCTION}

The Constitution of Brazil is celebrating its $30^{\text {th }}$ anniversary in 2018. According to one commentator, its text shows a constitution which is "reasonably advanced" and whose innovations are relevant not only to Brazilian but also to "worldwide constitutionalism".' How does Chile view the Brazilian experience? How has this advanced constitutionalism impacted us? The answer seems both embarrassing and intriguing. A quick survey on Chilean constitutional scholarship shows references to Brazil's Constitution and constitutionalism to be virtually non-existent. The most cited, as well as required, constitutional law handbooks practically do not mention any regulation, let alone development, of what Figueiredo labels as Brazil's advanced constitutionalism. It is true that amidst our own discussion on constitutional change some have revived (mostly to challenge those who favor a constituent assembly) the Brazilian experience of $1988 .^{2}$ Nevertheless, these scholars are still the exception within a scholarly trend that prefers to look to the Global North in search of (constitutional) experiences.

What explains this lack of attention? It is true that over the years we have developed a reverential fear towards Brazil when it comes to football. But that cannot seriously account for the scholarly aversion depicted above. Of course, there is also the language barrier. But it should not be deemed as an obstacle that is too burdensome. In fact, from a practical viewpoint both sides have come to idiomatic terms by resorting to what many call 'portuñol' - an informal mix of both Spanish and Portuguese. Furthermore, many legal practitioners have studied abroad and for some reason or another have paid attention to constitutional developments in other countries upon learning the

\footnotetext{
${ }^{1}$ FIGUEIREDO, Marcelo. La Evolución Político-Constitucional de Brasil. Revista Estudios Constitucionales, Santiago, año 6, n. 2, p. 209-246, 2008. p. 210.

${ }^{2} \mathrm{SOTO}$, Francisco. Las falacias sobre la asamblea constituyente. Reflexiones sobre el actual debate constitucional en Chile. In: CHIA, Eduardo; QUEZADA, Flavio (Eds.). Propuestas para una Nueva Constitución (Originada en democracia). Santiago: Instituto Igualdad - Facultad de Derecho de la Universidad de Chile - Friederich Ebert Stiftung, 2015. p. 88; SOTO, Francisco. Asamblea Constituyente: La experiencia Latinoamericana y el actual debate en Chile. Revista Estudios Constitucionales, Santiago, año 12, n. 1, p. 397-428, 2014. p. 408-9.
} 
countries' history and taking an interest in their constitutional schemes. We have done this even to the point of adjusting the Global South agenda to the academic interests of the Global North. To do all this, we have learnt a foreign language (English, French and German) and struggled to overcome other cultural barriers.

What is it, then? We devote this short essay to proposing some insights on the lack of regional dialogue, and from there suggest the major insights we have missed for not paying Brazil's constitutionalism its due. We do this in light of the Brazilian experience of constitutional enactment and amendments, and considering the debate underway in Chile from some time now about whether or not to change the constitution that was imposed during the dictatorship. The first section (2) explores the faults in which Chilean constitutional scholarship has incurred that explain this lack of attention. We suggest this is mainly due to a variant of constitutional colonialism. The following section (3) contends there are also faults that might be attributed to Brazilian constitutionalism itself, which has also - and, as we will describe, not necessarily because of the same reasons - dismissed regional dialogue. We believe this is due to Brazil's geopolitical, as well as to (4) the fact Brazil is a community proud of its Constitution, although not necessarily of its constitutional practice. This, we argue in the last section (5), should lead us to seriously (re)consider what we in Chile have hitherto missed: to see our own constitutional debate in light of the Brazilian experience, which shows its community was decided to transit from dictatorship to democracy by enacting a new constitution - whose $30^{\text {th }}$ birthday they now commemorate - .

\section{BRAZIL: A FOREIGN NEIGHBOR?}

Above we noted how little attention Chilean scholarship pays to the Brazilian constitutional system, the literature on it and Brazilian's high court decisions. Why this is so?

We suggest that, at least from Chile, there is a significant dose of academic colonialism which has closed new perspectives on the study of the constitutional systems of neighbor countries. In the field of Constitutional Law, academic colonialism can be understood as a selective reception and internalization of theoretical frameworks and scholarly ideas that influenced the local understanding of one's national constitution and political sovereignty under the terms of the Global North. It is part of a broader European and Anglo Saxon legal influence. ${ }^{3}$ This sort of colonialism is an heir of the influence of both the European and American constitutional projects in South America. ${ }^{4}$

\footnotetext{
${ }^{3}$ LÓPEZ MEDINA, Diego. Teoría Impura del Derecho. La transformación de la cultura jurídica latinoamericana. Bogotá: Legis, 2009. p. 1- 70.

${ }^{4}$ RODRÍGUEZ GARAVITO, César. Un nuevo mapa para el pensamiento jurídico latinoamericano. In: RODRÍGUEZ GARAVITO, César (Coord.). El Derecho en América Latina. Un mapa para el pensamiento jurídico del Siglo XXI. Buenos Aires: Siglo XXI Editores, 2011. p. 12.
} 
Scholarly colonialism is nothing new, but it has only recently been a matter of critical academic examination in the field of Latin American legal systems and counter -hegemonic studies. ${ }^{5}$ Some of those studies are inspired under new ways of rethinking academic paradigms in legal pluralistic contexts, especially those in which indigenous peoples cohabitate with the (now in crisis) national State ${ }^{6}$. In the field of Constitutional Law, the rise of new constitutional orders in Bolivia, Ecuador and Venezuela has led to a new understanding of, one, the definition of fundamental rights and, two, the establishment of State powers. ${ }^{7}$ The emergence of the idea of a constitutionalism of the Global South is only recent. ${ }^{8}$ New Latin American constitutions were accompanied by a new way of thinking about constitutional law and the theoretical paradigms that legal studies should be framed under.

In the case of Chile, we suggest that the legal academia is clearly colonized by the Global North and that our country has not adopted a new constitution influenced by the rise of political movements. The latter issue is analyzed in the final section of this paper. Regarding the first issue -colonization of the Global North-some of the studies on the Chilean legal culture have stressed that, initially, French and Hispanic influence were decisive in the construction of legal jurisprudence in our country. ${ }^{9}$ In fact, Chile has a legal system that belongs to the family of civil law. ${ }^{10}$ Therefore, codification has

\footnotetext{
${ }^{5}$ See, in general, SANTOS, Boaventura de Sousa; RODRÍGUEZ GARAVITO, César. Law, politics, and the subaltern in counter-hegemonic globalization. In: SANTOS, Boaventura de Sousa; RODRÍGUEZ GARAVITO, César (Ed.). Law and Globalization from Below. Cambridge: Cambridge University Press, 2005. p. 1-26.

${ }^{6}$ TUHIWAI SMITH, Linda, A descolonizar las metodologías. Investigación y pueblos indígenas, Santiago: LOM editores, 2016; TULLY, James, Strange Multiplicity. Constitutionalism in an Age of Diversity. Cambridge: Cambridge University Press. 1995. p. 140-182; BALDI, César. Del Constitucionalismo Moderno al Nuevo Constitucionalismo Latinoamericano Descolonizador. Revista de Derechos Humanos y Estudios Sociales, vol. 5, n. 9. p. 51-72, 2013. p. 54-55.

${ }^{7}$ See, among many others, CASAL HERNÁNDEZ, Jesús María. El constitucionalismo latinoamericano y la oleada de reformas constitucionales en la región andina. Revista del Instituto Max Planck de Historia del Derecho Europeo, Múnich, No. 16, p. 13-66, 2010; VICIANO PASTOR, Roberto; MARTíNEZ DALMAU, Rubén. Aspectos generales del nuevo constitucionalismo latinoamericano. In: ÁVILA LINZAN, Luis Fernando (Ed.). Política, Justicia y Constitución. Quito: Corte Constitucional para el Período de Transición, 2012, p. 157-186; VICIANO PASTOR, Roberto; MARTÍNEZ DALMAU, Rubén. El nuevo constitucionalismo latinoamericano. Fundamentos para una construcción doctrinal. Revista General de Derecho Público Comparado. No. 9, p. 1-24, 2011. For other denominations of the new model of Latin American Constitutionalism, see TÓRTORA, Hugo. Cambios introducidos al sistema de derechos fundamentales por el Nuevo Constitucionalismo Latinoamericano Descolonizador. Valparaíso, 2017. 306 f. Thesis (Doctorate) - Doctorate in Law Program, Universidad de Valparaíso. In:critical terms, see GARGARELLA, Roberto. Latin American Constitutionalism 1810-2010. Oxford: Oxford University Press, 2013.
}

${ }^{8}$ BONILLA, Daniel (Ed.). Constitucionalismo del sur global. Bogotá: Siglo del Hombre Editores, 2015.

${ }^{9}$ BARAONA GONZÁLEZ, Jorge. La cultura jurídica chilena: apuntes históricos, tendencias y desafíos. Revista de Derecho de la Pontificia Universidad Católica de Valparaíso, Valparaíso, vol. 35, p. 427-448, 2010. On the Chilean Legal Culture, see SQUELLA, Agustín (Ed.). La Cultura Jurídica Chilena. Santiago: Corporación de Promoción Universitaria, 1992.

${ }^{10}$ On the Civil Law tradition, see DAVID, René; JAUFFRET-SPINOSI, Camille. Los Grandes Sistemas Jurídicos Contemporáneos. 11. ed. Ciudad de México: Universidad Autónoma de México, 2010; MERRYMAN, John 
shaped our legal cultural practices ${ }^{11}$ and, as such, scholars have gone back to Europe -for the most part- to grasp the theoretical apparatus to understand our legal system. If we look at the bibliography of the mainstream treatises or manuals on Constitutional Law, it is easy to see that most references are either local or European (mostly from Spain, though sometimes from the Anglo Saxon world. An examination of the bibliography of a sample of traditional Chilean Constitutional Law manuals reveals that authors like Evans de la Cuadra, ${ }^{12}$ Verdugo et al., ${ }^{13}$ Molina, ${ }^{14}$ Vivanco, ${ }^{15} \mathrm{Cea},{ }^{16}$ and Evans Espiñeira, ${ }^{17}$ among others, do not quote or resort to Brazilian texts. Works in Portuguese are scarcely cited. ${ }^{18}$

The legal inheritance of codification has also impacted our judicial practices. ${ }^{19}$ An unpublished empirical study has identified the secondary sources that the Chilean Constitutional Court has cited in its decisions (from 1981 to 2005, just before a major constitutional amendment augmented the powers of the court). ${ }^{20}$ The study shows that the most cited secondary source is the Dictionary of the Royal Spanish Academy (Real Academia Española) ${ }^{21}$. This is obviously a sign of the high degree of local colonialism in terms of language, one that can even dismisses national sovereignty under the dictates of a foreign monarchical institution on the meaning of the words of the

Henry; PÉREZ-PERDOMO, Rogelio. The Civil Law Tradition. An Introduction to the Legal Systems of Europe and Latin America. 3. ed. Stanford: Stanford University Press, 2007.

${ }^{11} \mathrm{See}$, in general, SQUELLA, Agustín. La Cultura Jurídica Chilena. In: SQUELLA, Agustín (Ed.). La Cultura Jurídica Chilena. Santiago: Corporación de Promoción Universitaria, 1992. p. 32-48.

${ }^{12}$ EVANS, Enrique. Los derechos constitucionales. 3. ed. Santiago: Editorial Jurídica de Chile, 2004.

${ }^{13}$ VERDUGO, Mario; PFEFFER, Emilio; NOGUEIRA, Humberto. 2.ed. Derecho Constitucional. Santiago: Editorial Jurídica de Chile, 2002.

${ }^{14}$ MOLINA, Hernán. Derecho Constitucional. 8.ed.Santiago: Lexis Nexis, 2008.

${ }^{15}$ VIVANCO, Ángela. Curso de Derecho Constitucional. 3.ed. Santiago, Ediciones Universidad Católica de Chile, 2015.

${ }^{16}$ CEA, José Luis. Derecho Constitucional Chileno. 2. ed. T. II. Santiago, Ediciones Universidad Católica de Chile, 2008.

${ }^{17}$ EVANS ESPIÑEIRA, Eugenio. La Constitución Explicada. 3. ed. Santiago: Legal Publishing, 2010.

${ }^{18} \mathrm{See}$, for example, some of the few exceptions, such as GARCÍA, Gonzalo; CONTRERAS, Pablo; MARTíNEZ, Victoria. Diccionario Constitucional Chileno. 2.ed. Santiago: Hueders, 2016. p. 205 (quoting Gomes Canotilho); NOGUEIRA, Humberto. Derecho Constitucional Chileno. Santiago: Thomson Reuters, T. I, 2012, p. 22 and 283 (quoting Luis Roberto Barroso) and T. III, p. 333 (quoting André Ramos Tavares).

${ }^{19}$ CORREA SUTIL, Jorge. La Cultura Jurídica Chilena en Relación a la Función Judicial. In: SQUELLA, Agustín (Ed.). La Cultura Jurídica Chilena. Santiago: Corporación de Promoción Universitaria, 1992. p. 87.

${ }^{20} \mathrm{ORTIZ}$, Leonardo. La Dogmática Jurídica en el Tribunal Constitucional Chileno. ¿Un Refuerzo Argumentativo Real o Aparente? Análisis Jurisprudencial desde 1981-2005. Santiago, 2016. 49 f. Thesis (Graduate) - Law School Program, Universidad Alberto Hurtado. You can check the tables with the references, the rankings and the graphs of this empirical study at https://www.pcontreras.net/investigaciones.html, where they have been uploaded.

${ }^{21}$ ORTIZ, Leonardo. La Dogmática Jurídica en el Tribunal Constitucional Chileno. ¿Un Refuerzo Argumentativo Real o Aparente? Análisis Jurisprudencial desde 1981-2005. Santiago, 2016. 49 f. Thesis (Graduate) - Law School Program, Universidad Alberto Hurtado. p. 22-30. 
Chilean constitution ${ }^{22}$. Most of the other secondary sources are either local or from a few Spanish speaking countries; none are from Brazil ${ }^{23}$. Among the five countries whose literature is most cited by the Court, we find three European countries of reference: Spain, Italy and France. ${ }^{24}$ The only Portuguese text cited by the Constitutional Court is the famous book by José Gomes Canotilho, a Portuguese constitutional law scholar. ${ }^{25}$

It remains to be seen if this scenario has recently changed or is about to change. However, the available data seemingly shows there is a shift from the symbolic status that Spain highly enjoyed to a new reverence to Anglo Saxon countries. Under the current national program for postgraduate scholarships, new academics are mainly being trained in countries such as the United Kingdom, the United States and Canada. According to the data presented by the National Commission for Scientific and Technological Research, since 1980 until present day, 251 scholarships have been awarded to study masters, doctoral and postdoctoral programs in Law. ${ }^{26}$ The United States leads the ranking of post-graduate destinations, with 138 scholarships granted to recipients who have graduated from a legal academic program in the North American country, and is followed by the United Kingdom (63) and Spain (21). No Latin American country has been a destination for graduate studies, and the only country in the Global South has been Singapore, with only one scholarship assigned. Suffice it to say, Chilean legal academia is being trained in the Global North.

Economic considerations have led Chilean attorneys to pay more and more attention to legal developments in the US, ${ }_{i}^{27}$ plus, prestige and symbolic recognition comes with masters and doctorate degrees from the North. What Rodríguez Garavito has stated in general terms is particularly applicable to the Chilean case:

\footnotetext{
${ }^{22}$ For a critique of this hermeneutic approach, see ZAPATA, Patricio. La Interpretación de la Constitución. Revista Chilena de Derecho, Vol. 17, p. 162-164. 1990; BASSA, Jaime. La interpretación de los derechos fundamentales. In: CONTRERAS, Pablo; SALGADO, Constanza. Manual sobre Derechos Fundamentales. Teoría General. Santiago: LOM ediciones, 2016.

${ }^{23}$ ORTIZ, Leonardo. La Dogmática Jurídica en el Tribunal Constitucional Chileno. ¿ Un Refuerzo Argumentativo Real o Aparente? Análisis Jurisprudencial desde 1981-2005. Santiago, 2016. 49 f. Thesis (Graduate) - Law School Program, Universidad Alberto Hurtado. p. 32.

${ }^{24}$ ORTIZ, Leonardo. La Dogmática Jurídica en el Tribunal Constitucional Chileno. ¿Un Refuerzo Argumentativo Real o Aparente? Análisis Jurisprudencial desde 1981-2005. Santiago, 2016. 49 f. Thesis (Graduate) - Law School Program, Universidad Alberto Hurtado. p. 32-33.

${ }^{25}$ STC Rol No 346-02, Apr. 8, 2002, cons. 51ㅜ, citing GOMES CANOTILHO, José. Derecho Constitucional y Teoría de la Constitución. Coimbra: Librería Almedina. 1999.

${ }^{26}$ See Comisión Nacional de Investigación Científica y Tecnológica, Becas según área de conocimiento OCDE y país de destino, available at https://app.powerbi.com/view?r=eyJrljoiMjBhNTU0ZTItNzJjNS00OWQwLThiMWMtOWI2ZGI1NjMONDZkliwidCI6ImU3M2FmMWRILWU5ZTYtNGM0OS1iMWUxLWZjNjg3ZjM2MjYONyIsImMiOjR9 [last visited on Apr. 05, 2018]. The data presented only covers students that have obtained the degree pursued and not currently enrolled students.

${ }^{27}$ BARAONA GONZÁLEZ, Jorge. La cultura jurídica chilena: apuntes históricos, tendencias y desafíos. Revista de Derecho de la Pontificia Universidad Católica de Valparaíso, Valparaíso, vol. 35, p. 427-448, 2010. p. 442443.
} 
In our texts and our classes, the intellectual production of the North is magnified disproportionately (and that of the South reduced accordingly), as in the classic Mercator maps. In effect, a disproportionately large portion of time, resources and energy of Southern jurists is consumed in assimilating, translating and glossing -or simply 'keeping up' with- the materials produced in the North. ${ }^{28}$

It seems that Chile only looks north and not across the Andes. Our neighbors especially Brazil- are not in the map of our readings as they are not the authorities cited in our cases nor do these countries serve as our destination for further education and post-graduate studies.

\section{BRAZIL AS A (PROUD CONSTITUTIONAL) CONTINENT: THE GE- OPOLITICAL GRAVITAS}

Nevertheless, 'it takes two to tango'. In this section, we will tentatively explore what can be called - borrowing from Donelly - Brazilian exceptionalism ${ }^{29}$ and briefly explore the reasons why Brazil has also been reluctant to build (constitutional) bridges with other countries in the region.

There might be a sensitive geopolitical reason that could explain the lack of attention to Brazilian constitutionalism in Chile -and the same probably goes for the rest of the Spanish speaking countries-. This is the fact that Brazil, because of both its political and economic size, may legitimately see itself, and be regarded by others, as a continent in itself (with its own preoccupations, developments, etc.), separate from other Latin American countries. Its dimensions are not something one can easily miss. Brazil is the largest country in South America in terms of territorial extension (8.515.759 $\mathrm{km} 2$ ) -followed by Argentina, which is around one fourth of its size $(2.780 .400 \mathrm{~km} 2)-{ }^{30}$ It is the fifth largest country in the world in terms of territorial surface area. ${ }^{31}$ According to the United Nations World Population Prospects, Brazil also has the fifth largest

\footnotetext{
${ }^{28}$ RODRÍGUEZ GARAVITO, César. Un nuevo mapa para el pensamiento jurídico latinoamericano. In: RODRÍGUEZ GARAVITO, César (Coord.). El Derecho en América Latina. Un mapa para el pensamiento jurídico del Siglo XXI. Buenos Aires: Siglo XXI Editores, 2011.p. 12 (translation is ours).

${ }^{29}$ According to Donelly, what defines what he termed American exceptionalism was "the belief that the United States is different from (and generally superior to) most other countries, in large part because of its commitment to individual rights". DONELLY, Jack, International human rights, 4 ed. Boulder: Westview Press, 2013. p. 87.

${ }^{30}$ Brazil's official data is taken from INSTITUTO BRASILEIRO DE GEOGRAFIA E ESTATÍSTICA. Área territorial Brasileira, available at https://ww2.ibge.gov.br/home/geociencias/cartografia/default_territ_area.shtm> Last visited: Mar. 20, 2018.

${ }^{31}$ See UNITED NATIONS STATISTICS DIVISION, Demographic Yearbook - Table 3: Population by Sex, Rate of Population Increase, Surface Area and Density. Available at: <https://unstats.un.org/unsd/demographic/ products/dyb/dyb2012/Table03.pdf>. Last visited: Mar. 20, 2018.
} 
population with 209.288.278 inhabitants and is the most populated country in Latin America. ${ }^{32}$ Brazil is by far the largest democratic republic in Ibero-America and is the fourth largest democracy in the world (after India, the United States, and Indonesia)..$^{33}$

The economic power of Brazil is another factor that sets it apart from the rest of the countries in the region. Its Gross Domestic Product (GDP) was 1,796.19 USD Billions in 2016. ${ }^{34}$ If we compare Brazil with Argentina (545.90 USD Billions), ${ }^{35}$ Chile (247 USD Billions), ${ }^{36}$ or Colombia (282 USD Billions), it is not hard to understand how much further ahead Brazil is over the rest of the region. ${ }^{37}$ Brazil has taken a seat with other powerful nations with similar features; ${ }^{38}$ it is part of the BRICs, a term coined by Goldman Sachs to group the powerful rising economies of Brazil, Russia, India, and China. ${ }^{39}$

The size of a democracy -regarding territorial surface, population and GDP- is a feature that impacts both the internal process of self governance and its autonomy in relation to other countries ${ }^{40}$. It is a factor that concerns any comparative study of democracies. ${ }^{41}$ Large democracies are usually organized under federalism as a horizontal arrangement of separation of powers. According to Calabresi \& Bickford "[o]f the G-20 countries with the most important economies in the world, at least twelve have federal constitutional structures and several others are experimenting with federalism and the devolution of power. The first group includes [...] Brazil [...]."42 As one author noted, "[f]

32 UNITED NATIONS. World Population Prospects. The 2017 Revision. New York: United Nations, 2017. p. 17. Available at: <https://esa.un.org/unpd/wpp/publications/Files/WPP2017_KeyFindings.pdf>. Last visited: Mar. 20, 2018.

${ }^{33}$ Brazil's position is obtained when data from the UN Statistics Division are crossed and filtered under any ranking of democratic countries, such as one developed by The Economist Intelligence Unit or by Freedom House. See THE ECONOMIST. Democracy Index 2017. Available at: <https://www.eiu.com/public/topical_report.aspx?campaignid=Democracylndex2017>. Last visited: Mar. 20, 2018; FREEDOM HOUSE, Freedom in the World 2018. Available at: <https://freedomhouse.org/report/freedom-world/freedom-world-2018>. Last visited Mar. 20, 2018)

${ }^{34}$ TRADING ECONOMICS. Brazil GDP. Available at: <https://tradingeconomics.com/brazil/gdp>. Last visited: Mar. 20, 2018).

${ }^{35}$ TRADING ECONOMICS. Argentina GDP. Available at https://tradingeconomics.com/argentina/gdp > Last visited: Mar. 20, 2018).

${ }^{36}$ TRADING ECONOMICS. Chile GDP. Available at https://tradingeconomics.com/chile/gdp >. Last visited: Mar. 20, 2018).

${ }^{37}$ TRADING ECONOMICS. Colombia GDP. Available at https://tradingeconomics.com/colombia/gdp >. Last visited: Mar. 20, 2018).

${ }^{38}$ DAUVERGNE, Peter; FARIAS, Déborah, The Rise of Brazil as a Global Development Power. Third World Quarterly, Vol. 33, No. 5, p. 903-917, 2012.

${ }^{39} \mathrm{See}$, in general, ELLIOTT ARMIJO, Leslie. The BRICS Countries (Brazil, Russia, India, and China) as Analytical Category: Mirage or Insight: Mirage or Insight? Asian Perspective, Vol. 31, No. 4, p. 7-42, 2007. p. 8.

${ }^{40}$ DAHL, Robert Alan; TUFTE, Edward R. Size and democracy. Stanford: Stanford University Press. 1973; ALESINA, Alberto; SPOLAORE, Enrico. The Size of Nations. Cambridge: The MIT Press, 2003.

${ }^{41}$ LIJPHART, Arend, Patterns of Democracy. New Haven: Yale University Press, 1999. p. 60-61.

${ }^{42}$ CALABRESI, Steven G.; BICKFORD, Lucy D. Federalism and Subsidiarity: Perspectives From U.S. Constitutional Law. In: FLEMING, James E. \& LEVY, Jacob T. (Eds.). Nomos LV: Federalism and Subsidiarity. New York: New York University Press, 2014. p. 123. 
ederalism is presently far stronger in Brazil than in any other Latin American country."43 The type of interrelation between the federal level and the state level articulates a dynamic and vibrant federalism.

Assuming the size and federal arrangement of power in Brazil, it is not difficult to understand that this country is presented as a major self-governing unit which tends to engage in an inner self observation and reflection of the country's own dynamics, from the local to the national level and vice versa. These contextual factors constitute a framework for understanding how the Brazilian democratic transition constitutes a phenomenon of study that happens ad intra -within its borders- and becomes self-referential in academic terms.

\section{DEMOCRATIC TRANSITION AS A FACTOR FOR EXCEPTIONALISM}

Although geopolitical size may explain part of Brazilian exceptionalism, it is also worth exploring the way Brazilians see (and feel about) their constitution, for we believe this also sheds important light on, to the point it may actually justify, this inward -looking ethos. (As we will discuss later, this is precisely what we believe we have missed for not paying due attention to the Brazil constitutional evolution due attention.

Already a mature constitution, ${ }^{44}$ we believe it has built penetrating roots in both the Brazilian academia and citizenry. This attitude, we suggest here, fuels Brazil's geopolitical dimensions, thus producing a self-referential constitutional scheme. How was this attachment produced? There is a critical feature of Brazil's Constitution we must highlight: Brazil transitioned from dictatorship to democracy by enacting a new constitution. Other countries, such Chile, did not. Is this important in creating constitutional attachment? Let's see.

Brazilians discussed which would be the best means to enact a new constitution to welcome democracy. Two narratives were competing at the time. One narrative wanted to mark a decisive break with military dictatorship, and the other saw transition as the culmination of a gradual transformation, which the dictatorship both favored and permitted. ${ }^{45}$ The former, not surprisingly, pushed for a constituent assembly -the very means, as they saw it, that could embrace the constituent power needed to break with the past and represent the people's interests-. Not in vain, this position insisted the assembly's integration should be independent from congress. At the same time, they

\footnotetext{
${ }^{43}$ ROSENN, Keith S. Federalism in Brazil. Duquesne Law Review, Vol. 43, p. 577-598, 2005. p. 578.

${ }^{44}$ Elkins, Melton and Ginsburg "predicted lifespan for constitutions for all countries is 19 years". GINSBURG, Tom. Constitutional endurance. In: GINSBURG, Tom; DIXON, Rosalind (eds.). Comparative Constitutional Law. Cheltenham-Northampton: Edward Elgar, 2011. p. 112-125. p. 112.

${ }^{45}$ BARBOSA, Leonardo. História Constitucional Brasileira: Mudança constitucional, autoritarismo e democracia no Brasil pós-1964. 2 reimp. Brasília: Centro de Documentação e Informação-Edições Câmara, 2016, p. 204-205.
} 
claimed the assembly's exclusive task would be that of adopting a new constitution, thus not being distracted with governmental (day-to-day) politics.

The latter, instead, favored institutional means. Of course the constituent assembly itself is an institution, but those who preferred the "reconciliaçao and continuidade" path understood institutional means as a channel for the enactment of the new constitution through national congress. This congress would therefore exercise both its regular functions as well as its constituent powers. This is the position that prevailed. ${ }^{46}$ To take the words of Leonardo Barbosa, the "mudança constitutional" 47 was carried out by the very first democratic congress that followed dictatorship. ${ }^{48}$ This is why some have called this process of constitutional change a reform through transaction. ${ }^{49}$ In fact, many believe constitutional enactment occurred under heavy military tutelage, rendering the work of this so-called constituent congress nothing other than a democratic façade for what was de facto an elite-driven transition aimed at maintaining the status quo.

We believe it is wrong to read the work of that congress as simply pointing toward the idea of a regular congress that assumed constituent powers. First, as some have mentioned, Brazilian society, and accordingly its constitutional culture, was at the time already developing a political liberalization..$^{50}$ We can say it was a process of liberalization before democratization - which would be the goal of transition. This in part explains why the military were not in a particularly good standing to impose their views. ${ }^{51}$ Compare this with the Chilean case, once again, where the military dictatorship imposed a constitutional text in the middle of its regime and continued to resort to political terror.

Second, it is important to pay attention to the political significance surrounding the elaboration of the Constitution, for even if the means chosen was not a constituent assembly, the political environment was tellingly constituent. The 1986 democratic

\footnotetext{
${ }^{46}$ MARTÍNEZ-LARA, Javier. Building Democracy in Brazil: The politics of Constitutional Change, 1985-95. Basingstoke: Palgrave Macmillan, 1995. p. 55-60.

${ }^{47}$ BARBOSA, Leonardo. História Constitucional Brasileira: Mudança constitucional, autoritarismo e democracia no Brasil pós-1964. 2a reimp. Brasília: Centro de Documentação e Informação-Edições Câmara, 2016.

${ }^{48} \mathrm{~A}$ detailed description of these processes, and the debates the constitutional change sparked, can be consulted in MARTíNEZ-LARA, Javier. Building Democracy in Brazil: The politics of Constitutional Change, 198595. Basingstoke: Palgrave Macmillan, 1995.

${ }^{49}$ MUNCK, Gerardo; SKALNIK, Carol. Modes of Transition and Democratization: South America and Eastern Europe in Comparative Perspective. Comparative Politics, vol. 29, n. 3, p. 343-362, 1997. p. 347-351.

${ }^{50}$ MUNCK, Gerardo; SKALNIK, Carol. Modes of Transition and Democratization: South America and Eastern Europe in Comparative Perspective. Comparative Politics, vol. 29, n. 3, p. 343-362, 1997. p. 348.

${ }^{51}$ ZIMMERMANN, Augusto. Constitutions without constitutionalism: The failure of constitutionalism in Brazil. In: SELLERS, Mortimer; TOMASZEWSKI, Tadeusz (eds.). The Rule of Law in Comparative Perspective. Dordrecht: Springer, 2010, p. 135-45. p. 136. See also ROSENN, Keith. Brazil's New Constitution: An Exercise in Transient Constitutionalism for a Transitional Society. The American Journal of Comparative Law, Vol. 38, p. $773-$ 802. 1990. p. 775.
} 
elections in Brazil were not regular business. This was because not only were Brazilians returning to popular elections but, most importantly for our analysis here, because these elections were, although not in radical rupture with the past, certainly a decisive step toward "full restoration of democratic institutions".52 That restoration demanded a new constitutional scheme. To insist: despite the fact the process of constitutional replacement was eventually carried out by constituted institutions, they did so within the understanding 'something constituent' was happening. Not only did the elites understand this was the role the institutions were playing, but most importantly, the people understood this. In fact, many argue that during the constituent debates of the 1980's a new constitutional culture was developed, thus empowering grassroots organizations. $^{53}$

To be sure, it is not only that they see the 1988 constitution as democratically enacted because the politico-constitutional environment dictated so. As some authors have claimed, the very constituent process was both formally (institutionally) opened to gather popular inputs, as well as political (therefore not necessarily formal) and social.

Institutional openness was developed by different means at different stages of constituent conversations. At any rate, these instances of institutional participation existed and citizens made quite good use of them. Rossen perfectly summarizes what he calls a process crossed with 'unprecedented popular participation':

The Assembly's Internal Regulations required each subcommittee to devote five to eight sessions to hearing from entities representing different sectors of Brazilian society. Those heard included such diverse groups as government ministers, unions, landlords, Indians, street urchins, prostitutes, homosexuals, and maids. The Assembly established a computerized data bank containing the thousands of popular suggestions concerning the contents of the new constitution. During the seemingly interminable deliberations, virtually all aspects of Brazilian society were debated. ${ }^{54}$

Popular input was then not just a top-down graceful decision but a sort of unavoidable path the very transition - pushed from below - was taken to notice. First, it has been rightly claimed that strategic behavior analysis focuses heavily elites but little

\footnotetext{
${ }^{52}$ MARTÍNEZ-LARA, Javier. Building Democracy in Brazil: The politics of Constitutional Change, 1985-95. Basingstoke: Palgrave Macmillan, 1995. p. 45.

${ }^{53}$ ZAIDEN, Juliano. The forgotten people in Brazilian constitutionalism: Revisiting behavior strategic analyses of regime transitions. International Journal of Constitutional Law, Vol. 15, n. 2, p. 332-357, 2017. p. 346.

${ }^{54}$ ROSENN, Keith. Brazil's New Constitution: An Exercise in Transient Constitutionalism for a Transitional Society. The American Journal of Comparative Law, Vol. 38, p. 773-802. 1990. p. 777.
} 
on the people themselves. ${ }^{55}$ In fact, a closer look at the mobilizations occurring at the time show that (what Zaiden has termed) 'the forgotten people' played a critical role in contesting what started as an elite-driven process..$^{56}$ In the words of Leonardo Barbosa, social mobilization was successful in challenging the elitist turn the process took the outset, ${ }^{57}$ thus becoming "a fundamental source for understanding the potentiality of Brazil to turn the page on the past and to look to the eagerly awaited future".58 Political transition thus "became a constitutional transition".59

Finally, and probably one of the reasons ample debates were possible, congress decided constitutional change without a blueprint. This led them to enshrine almost all rights conceivably possible. As some have put it, this text represents an "exceptionally ambitious attempt[] to afford constitutional protection to individual" as well as collective rights. ${ }^{60}$ In fact, some have depicted the Brazilian Constitution as an "attempt to constitutionalize nearly every aspect of public life ...."61 From a purist viewpoint this may be seen as a reason to critique. In fact, it has been said Brazil's constitution fails to meet the minimum standards of a proper liberal Constitution as its programmatic turn - which has been said to look more like "a 'program of government' to be complied by the ordinary legislator"62 - departs from configuring a statute of power. Some lament the "lack of organic unity" the 1988 constitution shows, blaming the absence of a "master plan" that could have given the text some coherence. ${ }^{63}$

Others, however, rightly point to the mobilizations that were taking place as the constitution was being discussed. In the clarifying words of Conrado Hübner Mendes, one of the best reasons that could account for the social change inspiration embedded in the constitution is the politico-constitutional context itself against which

\footnotetext{
${ }^{55}$ See generally ZAIDEN, Juliano. The forgotten people in Brazilian constitutionalism: Revisiting behavior strategic analyses of regime transitions. International Journal of Constitutional Law, Vol. 15, n. 2, p. 332-357, 2017. ${ }^{56}$ ZAIDEN, Juliano. The forgotten people in Brazilian constitutionalism: Revisiting behavior strategic analyses of regime transitions. International Journal of Constitutional Law, Vol. 15, n. 2, p. 332-357, 2017. p. 344.

${ }^{57}$ BARBOSA, Leonardo. História Constitucional Brasileira: Mudança constitucional, autoritarismo e democracia no Brasil pós-1964. 2a reimp. Brasília: Centro de Documentação e Informação-Edições Câmara, 2016. p. 209.

${ }^{58}$ ZAIDEN, Juliano. The forgotten people in Brazilian constitutionalism: Revisiting behavior strategic analyses of regime transitions. International Journal of Constitutional Law, Vol. 15, n. 2, p. 332-357, 2017. p. 347.

${ }^{59}$ ZAIDEN, Juliano. The forgotten people in Brazilian constitutionalism: Revisiting behavior strategic analyses of regime transitions. International Journal of Constitutional Law, Vol. 15, n. 2, p. 332-357, 2017. p. 354.

${ }^{60}$ ROSSEN, Keith. A Comparison of the Protection of Individual Rights in the New Constitutions of Colombia and Brazil. Inter-American Law Review, Vol. 23, n. 3, p. 659-661. 1992. p. 660.

${ }^{61}$ ELKINS, Zachary; GINSBURG, Tom; MELTON, James, The Endurance of National Constitutions. Cambridge: Cambridge University Press, 2009. p. 6.

${ }^{62}$ ZIMMERMANN, Augusto. Constitutions without constitutionalism: The failure of constitutionalism in Brazil. In: SELLERS, Mortimer; TOMASZEWSKI, Tadeusz (eds.). The Rule of Law in Comparative Perspective. Dordrecht: Springer, 2010. p. 135-45. p. 138.

${ }^{63}$ ROSENN, Keith. Brazil's New Constitution: An Exercise in Transient Constitutionalism for a Transitional Society. The American Journal of Comparative Law, Vol. 38, p. 773-802. 1990. p. 779.
} 
these debates took place: "At that point, inscribing into the Brazilian Constitution the demands of each social movement was a symbolic and legitimizing act which had to be performed." 64

From a politico-constitutional side, therefore, this myriad of provisions may well account for the political processes that were unfolding at the time of its enactment, as well as reveal the goal Brazilians were pointing towards. ${ }^{65}$ As Hübner has contended, when seen from a comparativist viewpoint, the Brazilian Constitution "is surprising as it goes far beyond the fundamental constitutional compromises".66 In fact it is an example of directive constitutionalism, a form of constitutionalism aimed at achieving greater social justice and enhancing democratic participation, thus transforming, in the long run, social and political relations of power - what Klare termed as transformative constitutionalism when passing judgment on the South African Constitution of $1996 .{ }^{67}$

Whereas from a legalistic viewpoint these all-encompassing provisions may explain why it is virtually possible to question "every legislative decision", 68 their very same amplitude gives politics ample room to cope with the matters the people care the most about - what Tushnet aptly calls, constitutional matters ${ }^{69}$-, therefore developing a sense of constitutional usefulness/aptitude. ${ }^{70}$ This is opposed to other traditions such

\footnotetext{
${ }^{64}$ MENDES, Conrado Hübner. Constitutions and Institutions: Justice, Identity, and Reform. Judicial review of constitutional amendments in the Brazilian Supreme Court. Florida Journal of International Law, vol. 17, n. 3, p. 449-462, 2005. p. 452.

${ }^{65}$ We use the word 'goal' here not in a naive constitutional sense (as if constitutional provisions alone were enough to critically alter the material, symbolical, and cultural conditions of life of the people), but in a politically conscious fashion: considering the way constitutional provisions allow politics (broadly understood) to shape their implementation.

${ }^{66}$ MENDES, Conrado Hübner. Constitutions and Institutions: Justice, Identity, and Reform. Judicial review of constitutional amendments in the Brazilian Supreme Court. Florida Journal of International Law, vol. 17, n. 3, p. 449-462, 2005. p. 452.

${ }^{67} \mathrm{KLARE}$, Karl. Legal Culture and Transformative Constitutionalism. South African Journal on Human Rights, vol. 14. n. 1, p. 146-188. 1998. p. 150.

${ }^{68}$ MENDES, Conrado Hübner. Constitutions and Institutions: Justice, Identity, and Reform. Judicial review of constitutional amendments in the Brazilian Supreme Court. Florida Journal of International Law, vol. 17, n. 3, p. 449-462, 2005. p. 455.

${ }^{69}$ TUSHNET, Mark. Why the Constitution Matters. New Haven: Yale University Press, 2011.

${ }^{70} \mathrm{It}$ is true that under the auspices of the 1988 constitution courts, and particularly the Supremo Tribunal Feder$a l$, have been vigorated vis-à-vis the other branches thus promoting a more active role for judges. However, at the same time courts have developed -- as almost every other court in liberal democracies -- a certain political capacity to take care of their political capital. Thus, some studies show courts have been far from being either voracious activists or tremendously deferential to political power, developing an ambivalent stance. MENDES, Conrado Hübner. The Supreme Federal Tribunal of Brazil. In: JAKAB, András; DYEVRE, Arthur; ITZCOVICH, Giulio (eds.). Comparative Constitutional Reasoning. Cambridge: Cambridge University Press, 2017. p. 115-153. In:a similar vein, MOTTA FERRAZ, Octavio. Between activism and deference: social rights adjudication in the Brazilian Supreme Federal Tribunal. In: ALVIAR, Helena; KLARE, Karl; WILLIAMS, Lucy (eds.). Social and Economic Rights in Theory and Practice. Critical Inquiries. New York-London: Routledge, 2015. p. 121-137.
} 
as the one imposed in Chile, where the constitutional text tends to be seen exclusively as a set of restrictions that constrain politics. ${ }^{71}$

To sum up, we have argued that one reason that may explain Brazil's inward -looking constitutional attitude is its immense geopolitical power. Coupled with a sort of constitutional colonialism - found both here and there -, there is little ground to build fluent constitutional dialogues in the region, more generally, and between Brazil and Chile, more specifically. The second reason, we ventured, may be related to Brazil's constituent power. Closer attention to the moment the constitutional text was being discussed allows us to see that a constitutional culture was being developed, one which built strong ties around the 1988 Constitution. We do not intend to pass any judgment on Brazilian politics, rather notice that since 1988 politics have taken place within the constitutional confines - even if interpreted in a questionable fashion. Both the democratic practices the constitution has fostered, as well as the foundational moment of 1988, have developed "the acknowledgment by the political forces [and those of the citizenry?] that the Brazilian Constitution is a norm to be taken seriously"72 Despite some claims here and there apropos Dilma's impeachment or Lula's arrest, there is no comprehensive claim demanding a constituent assembly and a new constitution.

\section{SOME CONCLUSIONS: EXCUSE US, WE ARE LOST}

After years of legislative debate, the Chilean Congress passed a labor reform. Among its many regulations, it included some measures to strengthen the power of unions. One of these measures was granting unions the exclusive power to collectively bargain. Large corporations, siding with right wing political parties, claimed that the regulation violated the individual right to collective bargain (there is no contradiction in this, though this is exactly what they argued). The Constitutional Court joined their reasoning. In so doing, it stated that the constitutional text is not neutral in these matters; no constitution is neutral, it further added. ${ }^{73}$

There is one sense in which this reasoning is trivial. It is of course true that constitutions are not neutral. We expect constitutions not to be neutral on configuring a democratic regime or a republican form of government, or on recognizing constitutional rights. However, the non-neutrality the Constitutional Court was talking about was

\footnotetext{
${ }^{71}$ Whereas it is true that under classical liberal constitutionalism constitutions are to set limits on power, the case of the Chilean constitution shows when these limits are imposed undemocratically, they only serve to petrify a certain (in this case, dictatorial) legacy. Professor Fernando Atria has insightfully show how the authoritarian drafters of 1980 took chance of the limitative character that accompanies constitutionalism in sketching a straight jacket for politics. ATRIA, Fernando. La Constitución Tramposa. Santiago: LOM Ediciones, 2013.

${ }^{72}$ MENDES, Conrado Hübner. Constitutions and Institutions: Justice, Identity, and Reform. Judicial review of constitutional amendments in the Brazilian Supreme Court. Florida Journal of International Law, vol. 17, n. 3, p. 449-462, 2005. p. 454.

${ }^{73}$ Tribunal Constitucional de Chile, Causa Rol 3016(3026)-2016, 19 May 2016, cons. 12.
} 
not this, rather regular decisions of the kind taken in "normal lawmaking". ${ }^{74}$ In fact the Court declared, probably with some embarrassment, that "this constitution has some singularities". It was as if it were acknowledging that some decisions normally expected to be defined by regular politics were already enshrined at constitutional level. ${ }^{75}$

This explains why there is a widespread crisis of constitutional legitimation in Chile. The constitution is rightly seen as the dictatorship's legacy, already defining the outcome of many matters politics should deal with. Whereas the rest of the countries in the region started to walk the transitional terrain by agreeing to new constitutional channels -Brazil included, as we have seen-, Chile's constitutional regime had been defined quite some time before the transition began. In fact, the Constitution was imposed in 1980, eight years before Pinochet was defeated in a plebiscite the dictator himself called expecting to be ratified in power in 1988. Chile's 1980 Constitution was, and still is, authoritarian. From a substantive viewpoint, the 1980 Constitution was not looking to foster a new democracy, but rather to protect the dictatorship's oeuvre from it. The objective was, thus, to shield it from future revisions, therefore placing a political program out of the reach of democratic politics.

This explains why social movements have long been asking (some as early as 1980) for a genuine constituent process to get rid of the constitutional heritage of the dictatorship. After assuming her second (non-consecutive) term, President Bachelet intended to answer these claims - constitutional replacement was a central part of her presidential campaign. On the thirteenth of October 2015, Bachelet announced what is now called the itinerary of the constituent process. That process finalized with a bill submitted before Congress proposing the amendment of the entire constitutional text. Bachelet submitted this bill five days before leaving office, with little political support and having had scarce (virtually no) contact with political parties, let alone social movements, during its drafting. The bill was drafted in secrecy and many contend it scarcely honored the participatory stages that took place a couple of years prior and involved more than 200,000 people.

What was the problem with the process? Different from the Brazilian experience (and others, such as that of Colombia in 1991), Bachelet's itinerary resorted to constituted (institutional) procedures not with the aim of activating the constituent agency of the people, but rather to suffocate it. It ended up constraining participation and channeling the debates through regular congress. It is true, as we have reviewed here, that Brazil also resorted to its national congress. But, as we have seen, Brazil did so with the firm political aim of overcoming the dictatorship's legacy. Chile, instead, resorted to constituted institutions basically to constrain the people's constituent agency and,

\footnotetext{
${ }^{74}$ ACKERMAN, Bruce. We The People 1: Foundations. Cambridge: Harvard University Press, 1991.

${ }^{75}$ Notice that this is not the typical anti constitutionalist claim. See WALDRON, Jeremy. A Right-Based Critique of Constitutional Rights. Oxford Journal of Legal Studies, Vol. 13, n. 1, p. 18-51, 1993.
} 
without learning from previous mistakes, thereby obliterating the potential to enact a democratic constitution.

What have we missed by paying no attention to Brazilian constitutionalism? Many things. Certainly one important lesson whose consequences we are now dealing with is the following: established (constituted) institutions can be resorted to in order to democratize constituent processes. Existing constitutional requirements may well function as catalyzers of constitutional replacement, and the goal of democratizing the process can only be achieved when the political elite - besides performing their historical role - are open to being seduced by the challenges of the citizens themselves.

\section{REFERENCES}

ACKERMAN, Bruce. We The People 1: Foundations. Cambridge: Harvard University Press, 1991. ALESINA, Alberto; SPOLAORE, Enrico. The Size of Nations. Cambridge: The MIT Press, 2003.

ATRIA, Fernando. La Constitución Tramposa. Santiago: LOM Ediciones, 2013.

BALDI, César. Del Constitucionalismo Moderno al Nuevo Constitucionalismo Latinoamericano Descolonizador. Revista de Derechos Humanos y Estudios Sociales, vol. 5, n. 9. p. 51-72, 2013. BARAONA GONZÁLEZ, Jorge. La cultura jurídica chilena: apuntes históricos, tendencias y desafíos. Revista de Derecho de la Pontificia Universidad Católica de Valparaíso, Valparaíso, vol. 35, p. 427-448, 2010.

BARBOSA, Leonardo. História Constitucional Brasileira: Mudança constitucional, autoritarismo e democracia no Brasil pós-1964. 2 reimp. Brasília: Centro de Documentação e Informação-Edições Câmara, 2016.

BASSA, Jaime. La interpretación de los derechos fundamentales. In: CONTRERAS, Pablo; SALGADO, Constanza. Manual sobre Derechos Fundamentales. Teoría General. Santiago: LOM ediciones, 2016.

BONILLA, Daniel (Ed.). Constitucionalismo del sur global. Bogotá: Siglo del Hombre Editores, 2015.

CALABRESI, Steven G.; BICKFORD, Lucy D. Federalism and Subsidiarity: Perspectives From U.S. Constitutional Law. In: FLEMING, James E. \& LEVY, Jacob T. (Eds.). Nomos LV: Federalism and Subsidiarity. New York: New York University Press, 2014.

CASAL HERNÁNDEZ, Jesús María. El constitucionalismo latinoamericano y la oleada de reformas constitucionales en la región andina. Revista del Instituto Max Planck de Historia del Derecho Europeo, Múnich, No. 16, p. 13-66, 2010.

CEA, José Luis. Derecho Constitucional Chileno. 2. ed. T. II. Santiago, Ediciones Universidad Católica de Chile, 2008. 
CORREA SUTIL, Jorge. La Cultura Jurídica Chilena en Relación a la Función Judicial. In: SQUELLA, Agustín (Ed.). La Cultura Jurídica Chilena. Santiago: Corporación de Promoción Universitaria, 1992.

DAHL, Robert Alan; TUFTE, Edward R. Size and democracy. Stanford: Stanford University Press. 1973.

DAUVERGNE, Peter; FARIAS, Déborah, The Rise of Brazil as a Global Development Power. Third World Quarterly, Vol. 33, No. 5, p. 903-917, 2012.

DAVID, René; JAUFFRET-SPINOSI, Camille. Los Grandes Sistemas Jurídicos Contemporáneos. 11. ed. Ciudad de México: Universidad Autónoma de México, 2010.

DONELLY, Jack, International human rights. 4 ed. Boulder: Westview Press, 2013.

ELKINS, Zachary; GINSBURG, Tom; MELTON, James, The Endurance of National Constitutions. Cambridge: Cambridge University Press, 2009.

ELLIOTT ARMIJO, Leslie. The BRICS Countries (Brazil, Russia, India, and China) as Analytical Category: Mirage or Insight: Mirage or Insight? Asian Perspective, Vol. 31, No. 4, p. 7-42, 2007.

EVANS ESPIÑEIRA, Eugenio. La Constitución Explicada. 3. ed. Santiago: Legal Publishing, 2010.

EVANS, Enrique. Los derechos constitucionales. 3. ed. Santiago: Editorial Jurídica de Chile, 2004.

FIGUEIREDO, Marcelo. La Evolución Político-Constitucional de Brasil. Revista Estudios Constitucionales, Santiago, año 6, n. 2, p. 209-246, 2008.

GARCÍA, Gonzalo; CONTRERAS, Pablo; MARTÍNEZ, Victoria. Diccionario Constitucional Chileno. 2. ed. Santiago: Hueders, 2016.

GARGARELLA, Roberto. Latin American Constitutionalism 1810-2010. Oxford: Oxford University Press, 2013.

GINSBURG, Tom. Constitutional endurance. In: GINSBURG, Tom; DIXON, Rosalind (eds.). Comparative Constitutional Law. Cheltenham-Northampton: Edward Elgar, 2011. p. 112-125.

GOMES CANOTILHO, José. Derecho Constitucional y Teoría de la Constitución. Coimbra: Librería Almedina. 1999.

MENDES, Conrado Hübner. Constitutions and Institutions: Justice, Identity, and Reform. Judicial review of constitutional amendments in the Brazilian Supreme Court. Florida Journal of International Law, vol. 17, n. 3, p. 449-462, 2005.

MENDES, Conrado Hübner. The Supreme Federal Tribunal of Brazil. In: JAKAB, András; DYEVRE, Arthur; ITZCOVICH, Giulio (eds.). Comparative Constitutional Reasoning. Cambridge: Cambridge University Press, 2017. p. 115-153.

KLARE, Karl. Legal Culture and Transformative Constitutionalism. South African Journal on Human Rights, vol. 14. n. 1, p. 146-188. 1998. 
LIJPHART, Arend, Patterns of Democracy. New Haven: Yale University Press, 1999.

LÓPEZ MEDINA, Diego. Teoría Impura del Derecho. La transformación de la cultura jurídica latinoamericana. Bogotá: Legis, 2009.

MARTÍNEZ-LARA, Javier. Building Democracy in Brazil: The politics of Constitutional Change, 1985-95. Basingstoke: Palgrave Macmillan, 1995.

MERRYMAN, John Henry; PÉREZ-PERDOMO, Rogelio. The Civil Law Tradition. An Introduction to the Legal Systems of Europe and Latin America. 3. ed. Stanford: Stanford University Press, 2007.

MOLINA, Hernán. Derecho Constitucional. 8.ed. Santiago: Lexis Nexis, 2008.

MOTTA FERRAZ, Octavio. Between activism and deference: social rights adjudication in the Brazilian Supreme Federal Tribunal. In: ALVIAR, Helena; KLARE, Karl; WILLIAMS, Lucy (eds.). Social and Economic Rights in Theory and Practice. Critical Inquiries. New York-London: Routledge, 2015. p.121-137.

MUNCK, Gerardo; SKALNIK, Carol. Modes of Transition and Democratization: South America and Eastern Europe in Comparative Perspective. Comparative Politics, vol. 29, n. 3, p. 343-362. 1997.

NOGUEIRA, Humberto. Derecho Constitucional Chileno. Santiago: Thomson Reuters, T. I, 2012.

ORTIZ, Leonardo. La Dogmática Jurídica en el Tribunal Constitucional Chileno. ¿Un Refuerzo Argumentativo Real o Aparente? Análisis Jurisprudencial desde 1981-2005. Santiago, 2016. $49 \mathrm{f}$. Thesis (Graduate) - Law School Program, Universidad Alberto Hurtado.

RODRÍGUEZ GARAVITO, César. Un nuevo mapa para el pensamiento jurídico latinoamericano. In: RODRÍGUEZ GARAVITO, César (Coord.). El Derecho en América Latina. Un mapa para el pensamiento jurídico del Siglo XXI. Buenos Aires: Siglo XXI Editores, 2011.

ROSENN, Keith S. Federalism in Brazil. Duquesne Law Review, Vol. 43, p. 577-598, 2005.

ROSENN, Keith S. Brazil's New Constitution: An Exercise in Transient Constitutionalism for a Transitional Society. The American Journal of Comparative Law, Vol. 38, p. 773-802. 1990.

ROSENN, Keith S. A Comparison of the Protection of Individual Rights in the New Constitutions of Colombia and Brazil. Inter-American Law Review, Vol. 23, n. 3, p. 659-661. 1992.

SANTOS, Boaventura de Sousa; RODRÍGUEZ GARAVITO, César. Law, politics, and the subaltern in counter-hegemonic globalization. In: SANTOS, Boaventura de Sousa; RODRÍGUEZ GARAVITO, César (Ed.). Law and Globalization from Below. Cambridge: Cambridge University Press, 2005. p. $1-26$.

SQUELLA, Agustín (Ed.). La Cultura Jurídica Chilena. Santiago: Corporación de Promoción Universitaria, 1992.

SOTO, Francisco. Asamblea Constituyente: La experiencia Latinoamericana y el actual debate en Chile. Revista Estudios Constitucionales, Santiago, año 12, n. 1, p. 397-428, 2014. 
SOTO, Francisco. Las falacias sobre la asamblea constituyente. Reflexiones sobre el actual debate constitucional en Chile. In: CHIA, Eduardo; QUEZADA, Flavio (Eds.). Propuestas para una Nueva Constitución (Originada en democracia). Santiago: Instituto Igualdad - Facultad de Derecho de la Universidad de Chile - Friederich Ebert Stiftung, 2015. p. 83-93.

SQUELLA, Agustín. La Cultura Jurídica Chilena. In SQUELLA, Agustín (Ed.). La Cultura Jurídica Chilena. Santiago: Corporación de Promoción Universitaria, 1992. p. 32-48.

TÓRTORA, Hugo. Cambios introducidos al sistema de derechos fundamentales por el Nuevo Constitucionalismo Latinoamericano Descolonizador. Valparaíso, 2017. 306 f. Thesis (Doctorate) - Doctorate in Law Program, Universidad de Valparaíso.

TUHIWAI SMITH, Linda, A descolonizar las metodologías. Investigación y pueblos indígenas, Santiago: LOM editores, 2016.

TULLY, James, Strange Multiplicity. Constitutionalism in an Age of Diversity. Cambridge: Cambridge University Press. 1995.

TUSHNET, Mark. Why the Constitution Matters. New Haven: Yale University Press, 2011.

VERDUGO, Mario; PFEFFER, Emilio; NOGUEIRA, Humberto. 2. ed. Derecho Constitucional. Santiago: Editorial Jurídica de Chile, 2002.

VICIANO PASTOR, Roberto; MARTÍNEZ DALMAU, Rubén. Aspectos generales del nuevo constitucionalismo latinoamericano. In: ÁVILA LINZAN, Luis Fernando (Ed.). Política, Justicia y Constitución. Quito: Corte Constitucional para el Período de Transición, 2012. p. 157-186.

VICIANO PASTOR, Roberto; MARTÍNEZ DALMAU, Rubén. El nuevo constitucionalismo latinoamericano. Fundamentos para una construcción doctrinal. Revista General de Derecho Público Comparado, No. 9, p. 1-24, 2011.

VIVANCO, Ángela. Curso de Derecho Constitucional. 3. ed. Santiago, Ediciones Universidad Católica de Chile, 2015.

WALDRON, Jeremy. A Right-Based Critique of Constitutional Rights. Oxford Journal of Legal Studies, Vol. 13, n. 1, p. 18-51, 1993.

ZAIDEN, Juliano. The forgotten people in Brazilian constitutionalism: Revisiting behavior strategic analyses of regime transitions. International Journal of Constitutional Law, Vol. 15, n. 2, p. 332$357,2017$.

ZAPATA, Patricio. La Interpretación de la Constitución. Revista Chilena de Derecho, Vol. 17, p. 162-164. 1990

ZIMMERMANN, Augusto. Constitutions without constitutionalism: The failure of constitutionalism in Brazil. In: SELLERS, Mortimer; TOMASZEWSKI, Tadeusz (eds.). The Rule of Law in Comparative Perspective. Dordrecht: Springer, 2010. p. 135-45. 